\title{
Pelatihan Pemanfaatan Sampah Plastik sebagai Material Produk Hiasan bagi Lulusan SMA di Kota Tangerang
}

\author{
Ali Ramadhan', Lelo Lelo², Ridwan Rasyid ${ }^{1}$ \\ ${ }^{1}$ Departemen Desain Produk, Fakultas Desain dan Seni Kreatif, ${ }^{2}$ Departemen Desain Interior, Fakultas Desain dan Seni Kreatif \\ Universitas Mercu Buana, JI. Raya, Meruya Selatan, Jakarta Barat, DKI Jakarta, 11650, Indonesia
}

\section{ARTICLE INFO: \\ Diterima: 2019-05-24 \\ Direvisi: 2019-10-19 \\ Disetujui: 2020-01-18}

\section{Keywords:}

Decoration; Plastic; Products; Utilization; Waste

\begin{abstract}
Nowadays, waste is one of the environmental problems, because plastic waste is known to have a long life to decompose in the soil. Ornamental products are one of the products that have good value and can be placed freely. This activity aims to develop knowledge in terms of making decorative products using plastic waste. Participants are high school graduates in Tangerang. By using training methods, ornamental products can be developed using basic plastic waste materials that have gone through the pre-processing stage. The training stage includes presentation, material selection, design, material processing, review, and display. The implementation of this activity, it was found that the use of plastic waste which is used as a base material for ornamental products can provide additional knowledge to high school graduates as well as increase the ability to practice in making design works. Participants had the opportunity to have income from the sale of the product design of the waste processing.
\end{abstract}

(C) 2020 Published by University of Merdeka Malang. This is an open access article distributed under the CC BY-SA 4.0 license (https://creativecommons.org/licenses/by-sa/4.0/)

How to cite: Ramadhan, A., Lelo, L., \& Rasyid, R. (2020). Pelatihan Pemanfaatan Sampah Plastik sebagai Material Produk Hiasan bagi Lulusan SMA di Kota Tangerang. Abdimas: Jurnal Pengabdian Masyarakat Universitas Merdeka Malang, 5(1), 1-17. https://doi.org/10.26905/abdimas.v5i1.3083

\section{PENDAHULUAN}

Sampah dianggap sebagai permasalahan yang serius karena berkaitan dengan pemakaian suatu barang. Jumlah sampah mengalami peningkatan seiring dengan adanya peningkatan manusia. Sampah plastik diketahui merupakan barang buangan berupa plastik yang dihasilkan dari suatu proses produksi baik industri maupun domestik rumah tangga atau yang lebih dikenal sebagai sampah yang kehadirannya pada waktu dan tempat tertentu tidak dikehendaki lingkungan karena dianggap sudah tidak memiliki nilai ekonomis (Pivnenko et al., 2016). Sumber sampah plastik tergantung pada produksi plastik itu sendiri dan digolongkan berdasarkan bahan dasar penyusunnya. Pemakaian plastik secara terus menerus akan menghabiskan beberapa sumber daya alam yang tidak dapat diperbaharui. Selain itu menghasilkan beberapa zat yang berbahaya bagi kesehatan manusia. Pemanfaatan limbah plastik merupakan upaya menekan pembuangan plastik seminimal mungkin yang dapat dilakukan dengan mendaur ulang. Berdasarkan hal tersebut, maka dapat terbuka peluang untuk dapat memanfaatkan sampah plastik secara lebih baik. Dengan 
ABDIMAS: Jurnal Pengabdian Masyarakat Universitas Merdeka Malang

Volume 5, No 1, Maret 2020: 1-17

memanfaatkan sampah plastik menjadi satu karya produk, maka sampah plastik secara tidak langsung dapat mengurangi dampak yang diterima lingkungan (Lewis et al, 2017). Walaupun terdapat peluang sampah plastik yang dapat terus meningkat, namun dengan memanfaatkan sampah plastik untuk dijadikan produk maka akan memberikan dampak kepada masyarakat dalam meningkatkan pengetahuan serta tidak menutup kemungkinan akan menghasilkan keuntungan secara ekonomis (Merrington, 2017).

Saat ini, salah satu solusi untuk mengatasi jumlah pertumbuhan sampah plastik adalah dilakukannya proses daur ulang, sehingga sampah plastik tersebut dapat bermanfaat kembali dan dapat memberikan nilai ekonomis yang cukup tinggi (Ragaert et al, 2017). Namun dalam kondisi tertentu, bahan plastik yang dihasilkan dari sampah plastik yang telah didaur ulang suatu saat akan tetap menjadi sampah, sehingga perlu adanya aktifitas yang dapat membantu untuk mengurangi pertumbuhan sampah plastik yaitu salah satunya dengan memanfaatkan sampah tersebut menjadi benda yang memiliki nilai dan tidak mudah untuk dibuang (Hand, 2018).

Pemanfaatan adalah tingkatan dimana seseorang percaya bahwa penggunaan suatu teknologi tertentu akan meningkatkan prestasi orang tersebut dan berdasarkan frekuensi dan diversitas teknologi yang digunakan (Adam, 1992). Selain itu, pemanfaatan juga dapat diartikan sebagai penggunaan satu faktor untuk pekerjaan lebih mudah, bermanfaat, meningkatkan produktifitas, efektifitas, dan meningkatkan kinerja pekerjaan (Richard, 2017).

Pemanfaatan memiliki tanggung jawab untuk menghubungkan seseorang dengan bahan dan aktivitas yang spesifik, menyiapkan berbagai macam hal agar dapat berinteraksi dengan bahan dan aktivitas yang dipilih (Gargiulo \& Bouck, 2019), memberikan bimbingan selama kegiatan, memberikan penilaian atas hasil yang dicapai, serta memasukannya ke dalam prosedur yang berkelanjutan sehingga menjadi mata rantai dari suatu proses (Rusman, 2011).

Sampah adalah material sisa yang tidak diinginkan setelah berakhirnya suatu proses. Nama plastik mewakil ribuan bahan yang berbeda sifat fisis, mekanis dan kimia (Crawford \& Martin, 2020). Secara garis besar plastik dapat digolongkan menjadi dua yakni plastik yang bersifat thermoplastik yang merupakan plastik dengan karakteristik dapat dibentuk kembali dengan mudah dan diproses menjadi bentuk lain (Ormondroyd \& Morris, 2018), dan yang bersifat thermoset yang merupakan plastik dengan karakteristik mengeras tidak dapat dilunakkan kembali (Crawford \& Martin, 2020). Banyak kegiatan yang dilakukan di masyarakat yang memanfaatkan limbah sampah (Anita, 2019; Arico \& Jayanthi, 2017; Sunarjo \& Yuniarti, 2017; Setiyawan, 2016).

Sampah diketahui sebagai "material sisa" yang tidak diinginkan setelah berakhirnya suatu proses. Sampah plastik juga diketahui sebagai sampah yang paling banyak dibuang oleh manusia karena tidak sedikit manusia yang menggunakan plastik untuk keperluan setiap hari dari pekerjaan yang kecil seperti membawa barang sampai ke tingkat industri (Selke \& Culter, 2016). Salah satu penanganan limbah sampah plastik adalah dengan membuang dan membakar. Saat ini, terdapat salah satu metode penanganan limbah plastik yang paling ideal adalah dengan mendaur ulang (Ragaert et al, 2017).

Secara umum, material merupakan bahan dasar untuk membuat atau membentuk sesuatu obyek untuk pengalaman indra dengan ciri-ciri keleluasan, masa, gerak, dan ditentukan oleh ruang dan waktu (Surdia \& Saito, 2005). Pemilihan material merupakan salah satu tahap dalam suatu proses perancangan. Perlu adanya pengetahuan dari ragam material yang sebaiknya digunakan untuk suatu produk (Lawrence, 1995). Kegiatan pemilihan material dan proses perancangan merupakan bagian yang terintegrasi dalam 


\section{Pelatihan Pemanfaatan Sampah Plastik sebagai Material Produk Hiasan bagi Lulusan SMA...}

Ali Ramadhan, Lelo Lelo, Ridwan Rasyid

perancangan. Jadi kemampuan dalam mengeksploitasi potensi dan karakteristik serta sifat material adalah esensial bagi seorang perancang (De Aguiar et al., 2017).

Produk hiasan dikenal sebagai produk yang memiliki fungsi hias. Dalam perkembangannya, terdapat dua jenis produk hiasan yaitu produk hiasan yang memiliki nilai estetik dan yang memiliki nilai fungsi (Hasan, 2019). Suatu produk dapat disebut sebagai produk hiasan apabila memiliki nilai estetik atau keindahan. Keindahan dapat dihasilkan dari pengolahan material untuk menghasilkan bentuk, warna dan tekstur yang indah (Harper, 2017). Dalam proses pembentukannya, setiap bahan memiliki peluang untuk menjadi produk hiasan termasuk bahan limbah.

Produk hiasan dapat dilihat dari fungsi dan posisinya ditempatkannya seperti posisi penempatannya di dalam rumah (interior) atau di luar rumah (eksterior) (Swift, 2018). Produk hiasan interior berfungsi untuk menghias dan membuat suasana tertentu di dalam ruangan, hiasan di dalam rumah sering disebut elemen estetis interior (Bell, 2019). Produk hiasan eksterior berfungsi untuk menghias pagar, taman, atau dinding bagian luar rumah (Harper, 2017).

Dalam proses pembentukannya, produk hiasan terdiri atas bahan utama dan bahan pendukung. Bahan utama dalam produk hiasan adalah yang memiliki nilai estetik, sedangkan bahan pendukung adalah yang berfungsi untuk konstruksi (Schwartz, 2016). Seperti adanya produk yang terbuat dari sampah plastik sebagai bahan utama pembentuknya dan penggunaan kawat atau benang untuk pendukung agar dapat menyatu dan berfungsi (Abarna et al, 2019).

Berdasarkan permasalahan tersebut, pemecahan masalah yang dilakukan adalah memberikan pelatihan dalam bentuk praktik untuk menambah pengetahuan dalam hal membuat produk hiasan dan salah satunya dengan memanfaatkan sampah plastik (Clark, 2019). Adapun kerangka solusi pemecahan masalah disajikan pada Gambar 1.

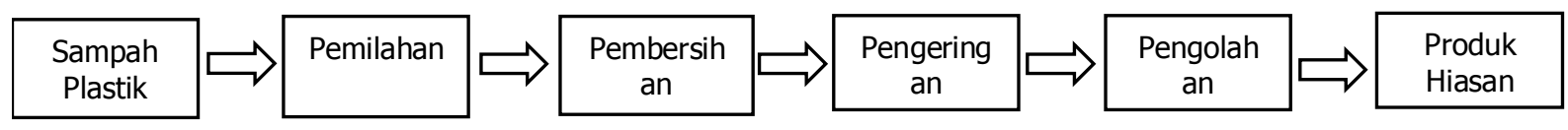

Gambar 1. Kerangka solusi pemecahan masalah

Praktik yang dilakukan untuk pembuatan produk hiasan diawali dengan memilah sampah yang layak untuk dijadikan bahan dasar dari produk hiasan. Dilanjutkan dengan pembersihan dengan cara dicuci lalu dikeringkan. Proses selanjutnya adalah pengolahan bentuk dengan menerapkan proses desain sehingga dapat menjadi suatu produk hiasan (Singh et al, 2017). Dengan adanya pelatihan tersebut dapat menjadi nilai tambah bagi peserta untuk dapat membantu pihak yang sedang atau akan menjalankan usaha untuk dapat mengembangkan UMKM yang berbasiskan produk sederhana (Singh \& Ordoñez, 2016).

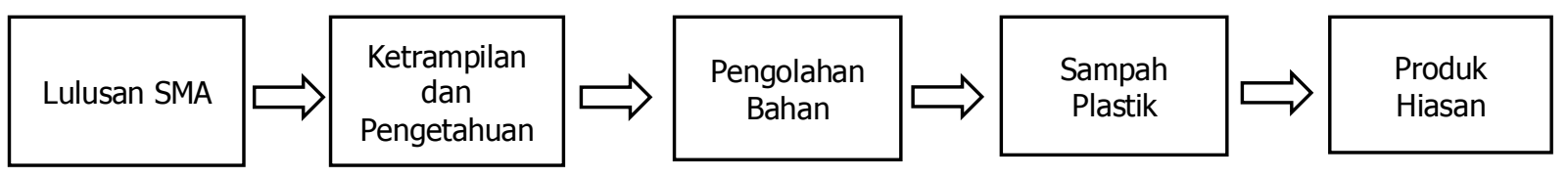

Gambar 2. Kerangka tujuan kegiatan

Selain hal yang menjadi solusi, pelatihan dimaksudkan untuk menambah wawasan dan pengetahuan seputar pembuatan produk khususnya produk hiasan untuk meningkatkan ketrampilan dalam pengolahan 
ABDIMAS: Jurnal Pengabdian Masyarakat Universitas Merdeka Malang

Volume 5, No 1, Maret 2020: 1-17

bahan yang dapat dimanfaatkan dari sampah untuk dijadikan produk hiasan (Charter \& Tischner, 2017). Adapun kerangka tujuan kegiatan disajikan pada Gambar 2.

\section{METODE}

Dalam pelaksanaan program pengabdian kepada masyarakat dalam bentuk pelatihan ini, terdapat dua metode pelaksanaan yaitu metode kegiatan dan rancangan evaluasi.

\section{Metode kegiatan}

Untuk pelaksanaan kegiatan dilakukan dengan menggunakan lima metode yaitu:

\section{Presentasi dan tanya jawab}

Metode presentasi digunakan untuk menjelaskan metode pelaksanaan program di setiap pertemuan agar para peserta dapat mengetahui aturan pelaksanaan dari kegiatan yang disertakan dengan pengenalan para tim pelaksana kegiatan kepada peserta. Selain itu, presentasi juga diperlukan untuk menjelaskan berbagai hal yang berkaitan dengan praktik yang akan dilakukan di setiap pertemuan. Selain presentasi, metode pelaksanaan juga menggunakan metode tanya jawab (Amalia \& Uswatun, 2019). Penggunaan metode ini dilakukan sebagai bentuk interaksi atau komunikasi yang dijalin antara tim pelaksana dengan peserta. Metode tanya jawab tidak hanya dilakukan di dalam ruangan, hal ini dimaksudkan untuk merespon keingintahuan peserta mengenai praktik yang sedang dilaksanakan. Metode tanya jawab dapat berkembang menjadi metode praktek jika tim pelaksana merasa perlu menunjukkan kepada peserta mengenai praktik yang sedang dilakukan. Hal ini agar para peserta dapat melihat dan mempraktikan secara langsung serta mendapatkan informasi serta penerapan yang maksimal (Hernawati \& Amin, 2017).

\section{Praktek}

Metode praktek dilakukan agar peserta dari pelatihan dapat langsung mengaplikasikan pengetahuan yang didapat dari penggunaan metode presentasi dan tanya jawab. Sebagai salah satu cara untuk dapat membantu peserta untuk memperdalam pengetahuannya maka instruktur juga akan menampilkan beberapa contoh yang telah diterapkan. Metode praktik yang dilaksanakan akan disertakan dengan bimbingan langsung kepada peserta untuk dapat menunjukkan proses dari praktik yang sedang dilakukan (Muhsinin et al., 2019).

\section{Modul}

Penggunaan modul dalam pelatihan ini, dimaksudkan untuk dijadikan sebagai bahan acuan peserta untuk mengetahui bentuk pemanfaatan sampah plastik. Isi dari modul yang digunakan merupakan beberapa hasil rangkuman penulisan yang dianggap perlu oleh tim pelaksana (Paulinan \& Purwanto, 2001).

\section{Rancangan evaluasi}

Dalam pelaksanaan program pengabdian dalam bentuk pelatihan ini terdapat 3 kriteria yang akan menjadi tolak ukur dasar pencapaian dari kegiatan pelatihan. 


\section{Pelatihan Pemanfaatan Sampah Plastik sebagai Material Produk Hiasan bagi Lulusan SMA...}

Ali Ramadhan, Lelo Lelo, Ridwan Rasyid

\section{Tolak ukur keberhasilan dari pelaksanaan}

Tolak ukur keberhasilan dari pelaksanaan kegiatan adalah dengan melaksanakan kegiatan sesuai dengan waktu dan jumlah pertemuan yang telah ditentukan sehingga perlu adanya kerjasama yang baik antara pelaksana dengan peserta.

\section{Tolak ukur keberhasilan dari peserta}

Tolak ukur keberhasilan dari pihak peserta antara lain adalah peserta mampu mempraktekkan atau menerapkan secara individu dan mengetahui metode yang digunakan untuk memanfaatkan bahan sampah plastik untuk membuat produk hiasan.

\section{Tolak ukur keberhasilan tim pelaksana}

Tolak ukur keberhasilan dari pihak pelaksana adalah mampu memberikan penjelasan serta bantuan yang dapat membantu peserta yang menagalami kesulitan dalam melakukan praktik membuat produk. Selain itu, keberhasilan tim pelaksana juga dapat diukur dari pelayanan yang baik dalam melakukan komunikasi pada saat pelaksanaan kegiatan serta kesesuaian jumlah kehadiran tim pelaksana yang sesuai dengan jumlah pertemuan yang telah ditentukan.

\section{HASIL DAN PEMBAHASAN}

Pelaksanaan merupakan tahap ketiga dari berbagai tahapan kegiatan program pengabdian pada masyarakat yang dilakukan. Pelaksanaannya dibagi kedalam dua tahap yaitu:

Tahap pertama, berupa penjelasan dari aktifitas yang dilakukan pada saat pelaksanaan pelatihan dan juga penjelasan berupa materi praktik dari pelatihan. Dalam penerapannya, pelaksanaan pelatihan ini dilakukan dalam 7 pertemuan yang dibagi ke dalam 3 aktifitas yaitu pengenalan, pelaksanaan dan penutupan Aktifitas pengenalan yang dilakukan dengan menjelaskan aktifitas yang akan dilakukan dan pemberian alat yang akan digunakan. Aktifitas pelaksanaan berhubungan dengan praktik aktifitas pelaksanaan dan aktifitas penutupan berupa penutupan acara kegiatan. Tahap pelaksanaan pelatihan dilakukan dalam beberapa aktifitas. Tahap kedua adalah tahap evaluasi. Dalam tahapan ini, pelaksana melakukan evaluasi terhadap rencana dengan realisasi pelaksanaan. Juga, mengevaluasi hambatan-hambatan yang terjadi serta solusi yang dapat dilakukan.

\section{Tahapan pelaksanaan}

\section{Presentasi}

Pada tahap ini, presentasi berupa penjelasan aktifitas yang akan dilakukan dan menjelaskan penggunaan material yang disertakan praktik serta menjelaskan teknik yang akan digunakan dalam pembuatan objek karya (Zainuddin et al, 2019). Pada saat presentasi ini juga diberikan gambaran contoh dari produk yang sejenis dari karya yang akan dibuat. Hal ini dimaksudkan agar peserta dapat mengetahui produk apa saja yang dapat dan telah dibuat melalui pemanfaatan sampah botol plastik menjadi produk hiasan. 


\section{ABDIMAS: Jurnal Pengabdian Masyarakat Universitas Merdeka Malang}

Volume 5, No 1, Maret 2020: 1-17

\section{Pemilihan bahan}

Pada tahap ini bertujuan agar peserta dapat mengetahui bahan plastik yang dapat digunakan untuk membuat produk hiasan. Hal ini dilaksanakan Sebagai bekal dari menambah pengetahuan dan kemampuan praktik dari peserta mengenai bahan dasar dari suatu produk dan khususnya produk yang dihasilkan dari bahan bekas (Sholihah et al, 2019).

\section{Perancangan (desain)}

Tahap ini merupakan tahap yang bertujuan untuk menambah kemampuan praktik khususnya tahap dalam merancang produk. Hasil desain dari peserta dilihat dari sudut pandang sketsa dan kemudahan dalam membuat rancangan (Anita \& Puspitasari, 2019). Hal ini dikarenakan agar produk yang dibuat dapat diterapkan dan dibuat tanpa menyulitkan peserta.

\section{Pengolahan bahan}

Pada tahap ini, pengolahan bahan dimaksudkan peserta dapat mengolah bahan yang digunakan agar dapat diterapkan sebagai produk hiasan. Dalam tahap pengolahan bahan, berbagai macam metode digunakan agar pada saat pembuatan dan penerapan ke dalam suatu produk dapat memberikan hasil yang baik dan sesuai dengan yang diinginkan (Arico \& Jayanthi, 2017).

\section{Review}

Pada tahap ini merupakan tahap akhir dari pelaksanaan program pengabdian masyarakat dalam bentuk pelatihan perancangan ini. Hasil yang telah dibuat oleh peserta diperlihatkan kembali sebagai suatu karya hasil rancangan sehingga dalam penerapannya, kegiatan pada tahap ini akan disertakan penjelasan oleh tim instruktur mengenai produk hiasan yang dibuat (Savitri \& Sriwardani, 2018).

\section{Display}

Selain pelatihan pembuatan produk hiasan memanfaatkan material plastik bekas. Pada tahap akhir juga akan melakukan tahap display. Yang dimaksudkan untuk memberikan gambaran nyata mengenai penerapan produk hiasan berdasar kepada keinginan peserta (Agustin, 2018). Hal ini dimaksudkan untuk dapat memberikan gambaran kondisi nyata mengenai tempat penerapan dari produk hiasan yang telah dibuat.

\section{Penutupan}

Tahap akhir yang merupakan pertemuan ke 7 yaitu sesi penutupan acara. Bentuk penerapannya berupa sesi perpisahan pihak tim instruktur dengan peserta yang dilangsungkan di Balai Warga Jl. Betet Raya, Kelurahan Cibodasari, Kecamatan/Desa Cibodas, Kota Tangerang, Banten, Indonesia.

\section{Materi kegiatan}

Dalam program pengabdian pada masyarakat ini, materi yang digunakan dalam pelaksanaan kali ini telah disesuaikan dari bahan ajar dan hasil dari penelitian yang pernah dilakukan oleh salah satu dari tim 


\section{Pelatihan Pemanfaatan Sampah Plastik sebagai Material Produk Hiasan bagi Lulusan SMA...}

Ali Ramadhan, Lelo Lelo, Ridwan Rasyid

pelaksana. Materi pelatihan yang digunakan dalam pelaksanaan program ini dibuat berdasarkan hasil penelitian serta rangkuman dari berbagai referensi yang berkaitan dengan pengolahan dan pemafaatan dari sampah plastik (Ahvenainen, 2003). Serta referensi dari pelaksanaan sejenis yang sudah pernah dilakukan oleh orang lain sebelumnya.

Materi yang diberikan pada pelaksanaan program pengabdian ini disesuaikan dari materi yang telah ada dengan adanya penyesuaian terhadap jumlah pertemuan dari pelaksanaan serta berdasarkan dari pembicaraan dengan tim pelaksana program pengabdian yang berkoordinasi dengan pihak terkait dengan tempat pelaksanaan. Dalam penerapannya, pelaksanaan kegiatan pengabdian pada masyarakat ini dibagi menjadi 7 pertemuan untuk berpraktik yang di setiap pertemuannya mempraktekan materi dari bahan ajar.

Tabel 1. Jadwal pertemuan kegiatan pelatihan

\begin{tabular}{|c|c|}
\hline \multicolumn{2}{|c|}{ Pertemuan 1} \\
\hline Aktifitas & $\begin{array}{l}\text { - Penjelasan metode pelaksanaan } \\
\text { - Perkenalan kelompok pelaksana } \\
\text { - Pengenalan peralatan yang akan digunakan } \\
\text { - Pengenalan contoh karya yang akan dibuat pada pelaksanaan program pengabdian }\end{array}$ \\
\hline Tujuan & $\begin{array}{l}\text { - Mengenalkan metode pelaksanaan program pengabdian dan pengenalan kelompok (tim } \\
\text { pelaksana). } \\
\text { - Memberikan pengenalan peralatan yang digunakan dalam pelaksanaan program pengabdian } \\
\text { ini serta contoh karya yang akan dijadikan acuan dalam pelaksanaan program pengabdian. }\end{array}$ \\
\hline \multicolumn{2}{|c|}{ Pertemuan 2} \\
\hline Aktifitas & $\begin{array}{l}\text { - Pemilihan bahan yang akan digunakan } \\
\text { - Proses pembersihan dari kotoran yang menempel pada bahan }\end{array}$ \\
\hline Tujuan & $\begin{array}{l}\text { - Untuk dapat memberikan pengetahuan kepada peserta mengenai syarat-syarat dari } \\
\text { pemanfaatan material sampah plastik yang dapat digunakan untuk menghasilkan produk hiasan. } \\
\text { - Membersihkan sampah plastik yang telah dipilah untuk diolah menjadi produk hiasan yang } \\
\text { diinginkan. }\end{array}$ \\
\hline \multicolumn{2}{|c|}{ Pertemuan 3} \\
\hline Aktifitas & $\begin{array}{l}\text { - Penjelasan bentuk yang akan dibuat yang disertakan penjelasan metode pembuatan } \\
\text { - Pengeringan bahan menggunakan teknik pengelapan dan penjemuran }\end{array}$ \\
\hline Tujuan & $\begin{array}{l}\text { - Untuk memberikan pengetahuan mengenai proses pengeringan yang perlu dilakukan untuk } \\
\text { material plastik agar bahan tersebut dapat dimanfaatkan. } \\
\text { - Menjelaskan bentuk yang akan dibuat sebagai teknik dasar untuk mencapai bentuk yang } \\
\text { diinginkan. }\end{array}$ \\
\hline \multicolumn{2}{|c|}{ Pertemuan 4} \\
\hline Aktifitas & $\begin{array}{l}\text { - Pembuatan rancangan produk yang akan dibuat } \\
\text { - Pembuatan pola berdasarkan gambar yang telah dibuat }\end{array}$ \\
\hline Tujuan & $\begin{array}{l}\text { - Praktik yang sudah mengarah kepada pembuatan produk hiasan yang diawali dari membuat } \\
\text { rancangan serta pola dari rancangan yang telah dibuat agar dapat memberikan kesesuaian } \\
\text { antara hasil dengan fisik produk }\end{array}$ \\
\hline \multicolumn{2}{|c|}{ Pertemuan 5} \\
\hline Aktifitas & - Pengolahan bahan sesuai dengan bentuk rancangan \\
\hline Tujuan & $\begin{array}{l}\text { - Memberikan pengetahuan praktik yang menekankan kepada bentuk yang telah dibuat } \\
\text { disertakan dengan teknik dalam mengolah bentuk dari sampah plastik }\end{array}$ \\
\hline \multicolumn{2}{|c|}{ Pertemuan 6} \\
\hline Aktifitas & - Finishing \\
\hline & - Pewarnaan bahan yang sesuai dengan rancangan \\
\hline Tujuan & $\begin{array}{l}\text { - Memberikan proses finishing kepada produk hiasan agar dapat menampilkan hasil maksimal } \\
\text { untuk dapat dikategorikan kepada produk hiasan. Hal ini dikarenakan produk hiasan akan } \\
\text { menekankan kepada estetika dari objek yang terlihat. }\end{array}$ \\
\hline
\end{tabular}


ABDIMAS: Jurnal Pengabdian Masyarakat Universitas Merdeka Malang Volume 5, No 1, Maret 2020: 1-17

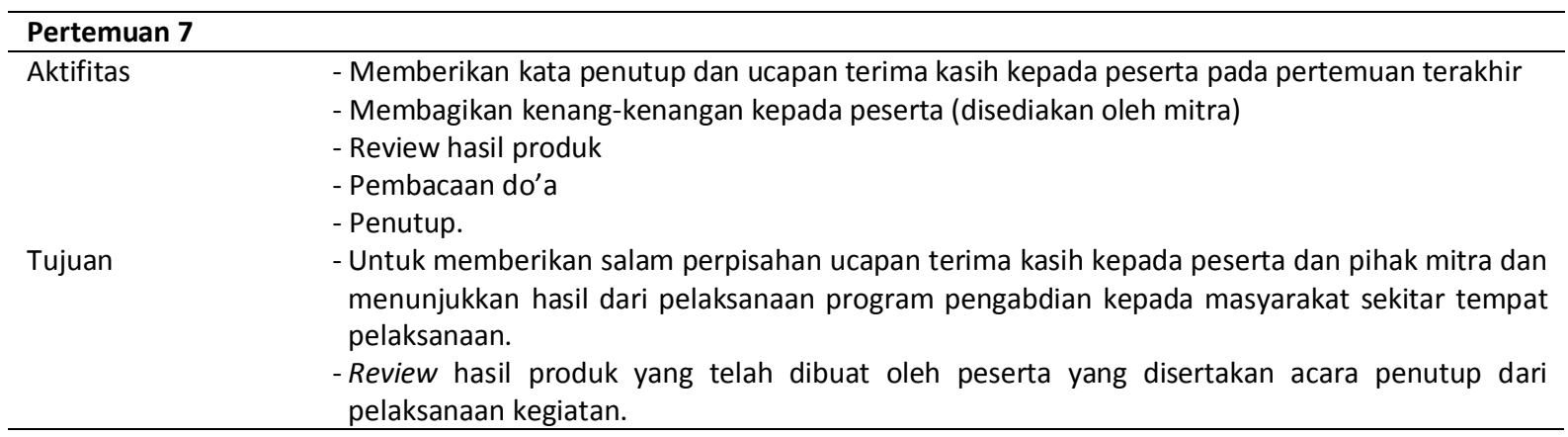

Dalam pelaksanaan hari pertama diawali dengan pengenalan tim pelaksana yang disertakan penjelasan metode pelaksanaan yang berupa penjelasan tata tertib pelaksanaan dan penggunaan peralatan yang disediakan oleh pihak tim pelaksana kepada pihak peserta dan mitra.

Pelaksanaan pertemuan pertama dilaksanakan di hadapan mitra dan peserta. Pada pertemuan pertama juga dilakukan penjelasan pengenalan peralatan yang akan digunakan pada pelaksanaan kegiatan pengabdian pada masyarakat yang diserta penjelasan mengenai penggunaan dari alat yang diberikan. Selain hal itu, pada pertemuan pertama juga akan diberikan beberapa contoh karya yang akan dibuat pada pelaksanaan di setiap pertemuannya.

Penjelasan tata tertib mengenai penggunaan fasilitas yang digunakan dimaksudkan agar peserta tidak melakukan hal-hal yang bertentangan dengan norma kepatutan serta menimalkan kegiatan yang bersifat negatif yang membutuhkan penggunaan peralatan yang dijadikan fasilitas. Seperti penggunaan alat tajam untuk keperluan lain.

Aktifitas yang dilakukan pada pertemuan kedua, pelaksanaan kegiatan berupa persiapan bahan yang akan digunakan serta pemilihan dan pembersihan dari kotoran yang melekat pada bahan yang akan digunakan.

Proses yang dilakukan pada saat pemilihan dan pembersihan kotoran pada material yang akan digunakan, dimaksudkan agar peserta dapat mengetahui syarat dan kriteria dari bahan plastik yang akan digunakan. Karena secara tidak langsung akan berpengaruh terhadap kualitas hasil jadi dari produk hiasan. Gambar 3 menyajikan aktivitas persiapan obyek yang digunakan dalam kegiatan pelatihan.
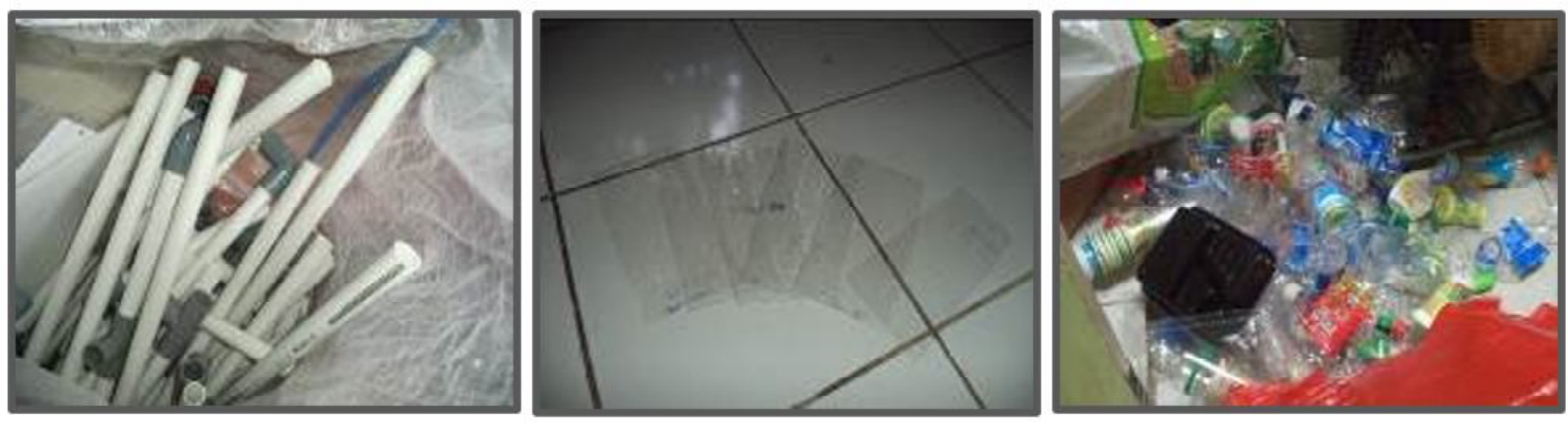

Gambar 3. Aktifitas persiapan objek

Pelatihan hari kedua ini secara langsung memberikan dampak positif, karena dengan adanya persiapan tersebut peserta dapat mengetahui ciri, syarat, dan kriteria material yang dapat digunakan untuk membuat produk. 


\section{Pelatihan Pemanfaatan Sampah Plastik sebagai Material Produk Hiasan bagi Lulusan SMA... \\ Ali Ramadhan, Lelo Lelo, Ridwan Rasyid}

Pertemuan ketiga adalah aktifitas yang dilakukan sudah mulai mempraktikan metode pembuatan dari objek yang ingin dibuat. Teknik yang digunakan untuk melaksanakan metode pembuatan disertakan dengan penjelasan dari praktik dan teknik dalam mengolah bahan palstik untuk dapat dijadikan bentuk dasar yang diinginkan. Selain itu, dalam prosesnya, setelah pelaksanaan pengolahan bentuk yang dilakukan. Peserta melaksanakan pembersihan material yang telah diolah. Selain agar untuk kebersihan dari material, juga dimaksudkan agar peserta apar melihat kondisi dari material yang akan digunakan.

Material yang digunakan pada pertemuan ini merupakan material yang sama yang telah dibersihkan. Selain itu, dalam pelaksanaan kegiatan ini, bahan yang telah dipilih dan diolah akan menjadi bahan dasar dari produk yang akan dibuat oleh setiap peserta. Oleh karena itu setiap peserta memiliki bahan atau material sesuai dengan keriteria dan rancangan yang ingin dibuat. Gambar 4 menunjukkan proses pengolahan bahan.
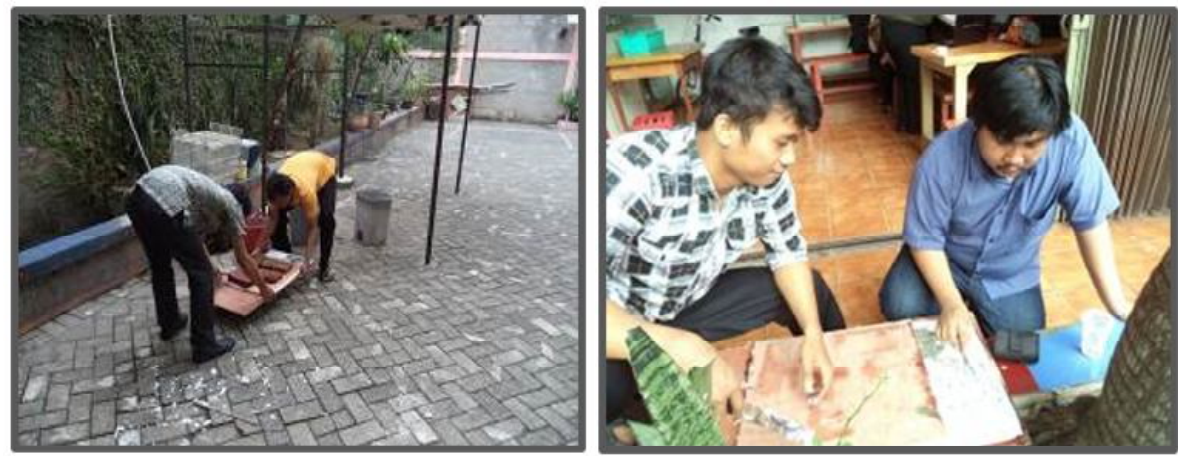

Gambar 4. Proses pengolahan bahan

Selain pengolahan bahan yang dilakukan, pada pertemuan kali ini juga diselingi dengan penjelasan mengenai teknik dalam mengolah bentuk dari bahan yang digunakan. Serta sesi komunikasi ide yang merupakan sesi tambahan. Karena dalam penerapannya, sesi ini lebih menekankan kepada komunikasi antara peserta dalam menjelaskan ide dan pelaksana untuk mencapai bentuk produk yang diinginkan. Oleh karena itu penyeleksian ide melalui gambar dilakukan oleh tim pelaksana di depan peserta untuk memberitahukan kelebihan dan kekurangan dari rancangan yang ingin dihasilkan oleh peserta.

Pada pertemuan keempat, aktifitas yang dilakukan pada pelaksanaan pengabdian pada masyarakat kali ini difokuskan kepada pembuatan rancangan produk yang akan dibuat. Serta pembuatan pola dari produk yang di rancang. Pembuatan rancangan ini dilakukan oleh setiap peserta dengan menggambar terlebih dahulu sketsa ide berupa bentuk dan fungsi dari produk yang diinginkan. Pelaksanaan kegiatan pertemuan keempat juga ditunjang dengan fasilitas kertas ukuran A4 untuk membuat sketsa dan kertas ukuran A3 untuk membuat pola dari produk yang akan dibuat.

Pada kedua aktifitas tersebut dimaksudkan agar para peserta dapat memberikan ide dasar dari produk yang akan dibuat dan setelahnya dapat memberikan kejelasan mengenai dimensi dan bentuk dasar dari produk hiasan yang dirancnag. Pihak pelaksana menyadari bahwa tidak semua peserta dapat mengkomunikasikan ide dasar yang mereka miliki menggunakan media gambar. Sehingga pada penguasaan teknik menggambar pada pelaksanaan aktifitas kali ini akan dibantu pihak tim pelaksana dengan membantuk membuatkan sketsa dasar dengan mengkomunikasikan dengan pihak peserta. Karena selain dikarenakan 
ABDIMAS: Jurnal Pengabdian Masyarakat Universitas Merdeka Malang

Volume 5, No 1, Maret 2020: 1-17

bentuk dasar dari produk hiasan juga perlu adanya komunikasi untuk mengetahui dimensi dan bahan utama yang akan diterapkan pada produk hiasan yang akan dibuat.
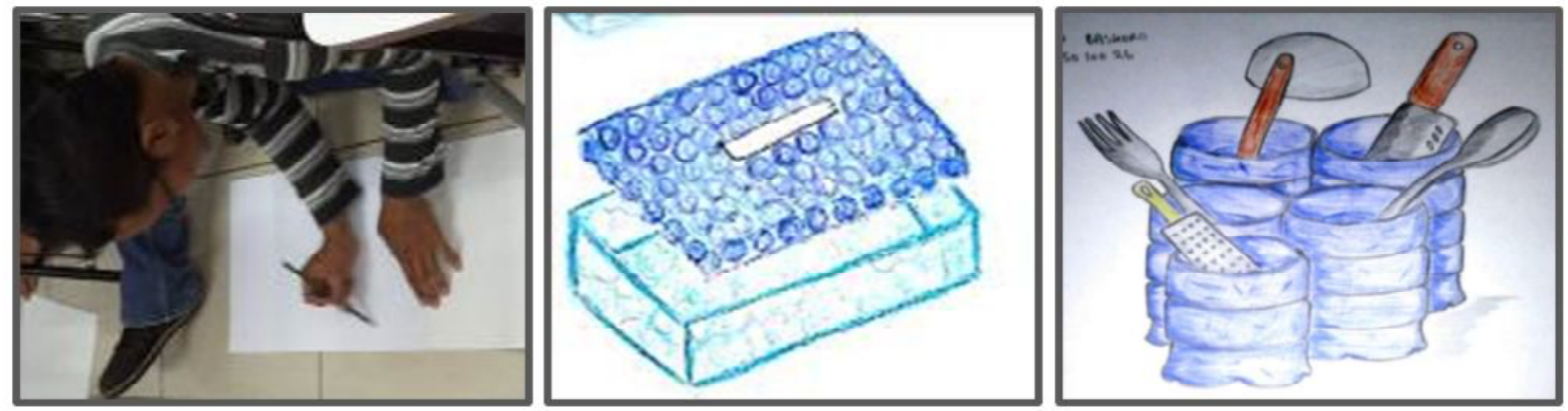

Gambar 5. Aktifitas perancangan produk

Pada pertemuan keempat kali ini adalah aktifitas pembuatan rancangan produk dan pembuatan pola (Gambar 5). Peserta diharapkan dapat mengetahui teknik menggambar berdasarkan ide yang dimiliki dan mampu untuk menerapkan ide dasar melalui pola dan dimensi dari produk yang dibuat. Hasil dari pelaksanaan hari keempat ini akan digunakan sebagai komponen pembentukan dari produk yang berguna untuk menerapkan rancangan menjadi produk hiasan.

Pada pertemuan kelima pelaksanaan program pengabdian yang dilakukan memasuki tahap pengolahan bahan. Dimulai dengan pengolahan bahan yang disesuaikan dengan bentuk rancangan yang telah dibuat oleh peserta. Teknik pengolahan dilakukan oleh peserta yang dibantu oleh pihak tim pelaksana. Berbagai macam teknik digunakan dalam pengolahan bentuk. Hal ini dimaksudkan untuk mencapai kesesuaian bentuk rancangan dengan yang diinginkan. Penyesuaian bentuk terkadang terjadi pada saat pembuatan bentuk dasar. Hal ini dikarenakan adanya penyesuaian material dengan bentuk yang dikaitkan dengan karakteristik dari bahan dasar yang dimanfaatkan. Seperti adanya bagian yang sulit untuk diolah maka bagian tersebut digantikan dengan bagian yang lain untuk mendapatkan bentuk yang diinginkan.

Dalam penerapan di pertemuan kelima ini instruktur ikut serta dalam pengolahan bahan. Pelaksana menyadari bahwa pengetahuan dalam praktik dari peserta masih perlu bimbingan. Oleh karena itu, komunikasi yang dijalin pada pertemuan kali ini sangan intens. Dengan adanya komunikasi yang dilakukan maka dapat meminimalkan kesalahan pengolahan bahan dan kesalahan bentuk, sehingga dapat mencapai titik tengah berupa toleransi bentuk yang diinginkan dari peserta yang dihubungkan dengan bentuk dan produk yang diinginkan. Gambar 6 menunjukkan hasil pengolahan bahan.
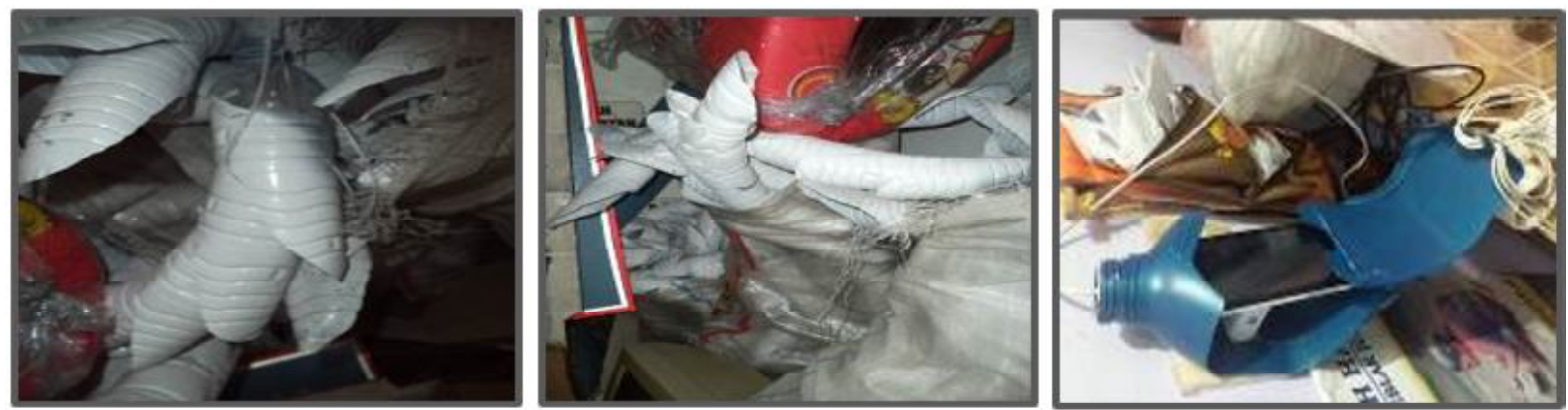

Gambar 6. Hasil pengolahan bahan 


\section{Pelatihan Pemanfaatan Sampah Plastik sebagai Material Produk Hiasan bagi Lulusan SMA...}

Ali Ramadhan, Lelo Lelo, Ridwan Rasyid

Pengolahan bahan dimaksudkan untuk memberikan pengetahuan dasar kepada peserta dalam melakukan pengolahan bahan dasar dari produk dalam menemukan bentuk yang disesuaikan dengan rancangan yang dibuat. Selain itu, pengolahan yang dilakukan juga dimaksudkan agar perserta dapat mengetahui teknik yang dilakukan dalam pengolahan bahan dalam penyesuaian bentuk dasar untuk dapat dikembangkan selanjutnya oleh peserta.

Pada pertemuan keenam, pelaksanaan kegiatan mengarah kepada finishing dari produk hiasan yang telah dibuat. Pelaksanaan tahap ini mengacu kepada pengecekan dari produk yang telah dibuat dan pewarnaan produk serta penepatan komponen tambahan yang akan menjadi daya tarik dari produk hiasan yang dibuat.

Pada tahap finishing, aktifitas yang dilakukan bertujuan untuk menampilkan hasil yang baik untuk dapat dijadikan produk hiasan. Tidak hanya pada keindahan bentuk namun juga dengan keindahan dari visual yang diberikan. Dalam pelaksanaannya, tidak semua produk harus diberikan finishing, karena dalam penerapannya, terdapat bahan yang dapat dikategorikan baik tanpa finishing. Namun dikarenakan perlu adanya penekanan keindahan terhadap produk hiasan maka pewarnaan pada produk hiasan tersebut akan menggunakan warna dasar transparan untuk menguatkan kesan warna dari produk hiasan. Pertimbangan dari pewarnaan ini adalah dengan melihat kondisi dari produk yang cukup baik tanpa adanya kekurangan berupa "cacat hasil". Gambar 7 menunjukkan contoh dari proses finishing produk.
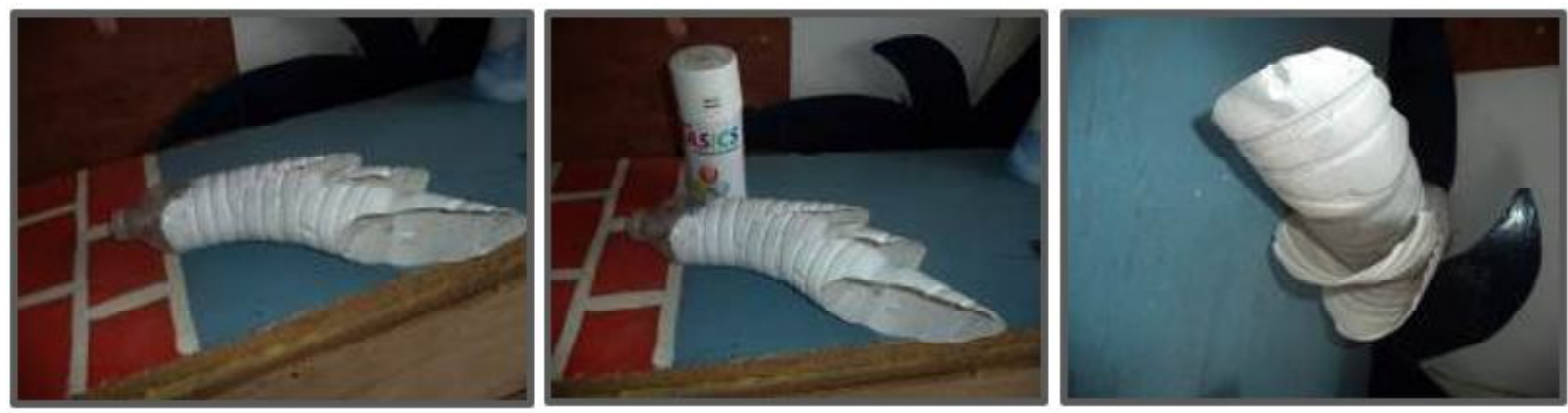

Gambar 7. Finishing produk

Metode pelaksanan yang dilakukan pada pertemuan ini tidak jauh berbeda seperti metode yang dilakukan pada pertemuan sebelumnya. Yaitu metode praktik berupa tutorial, yang menekankan kepada penjelasan mengenai praktik yang ditunjukkan oleh tim pelaksana yang selanjutnya dilanjutkan oleh para peserta untuk mengikuti teknik yang telah dipraktikan.

Pertemuan ketujuh merupakan pertemuan terakhir dari program pengabdian masyarakat ini. Aktifitas yang dilakukan pada pertemuan kali ini adalah penyampaian ucapan terima kasih oleh tim pelaksana program pengabdian pada masyarakat Universitas Mercu Buana melalui kata penutup yang dilanjutkan dengan ucapan terima kasih dari pihak mitra. Dilanjutkan dengan pemberian kenang-kenangan kepada peserta oleh pihak mitra.

Setelah aktifitas pemberian kata penutup dan kenang-kenangan. Maka aktifitas dilanjutkan dengan review hasil produk hiasan yang telah dibuat oleh peserta dengan disaksikan oleh pihak peserta dan mitra. Dalam penerapannya, review hasil karya tersebut dilakukan dalam bentuk pameran (display) karya dalam bentuk penerapan karya pada tempat yang ditetapkan. 
ABDIMAS: Jurnal Pengabdian Masyarakat Universitas Merdeka Malang Volume 5, No 1, Maret 2020: 1-17
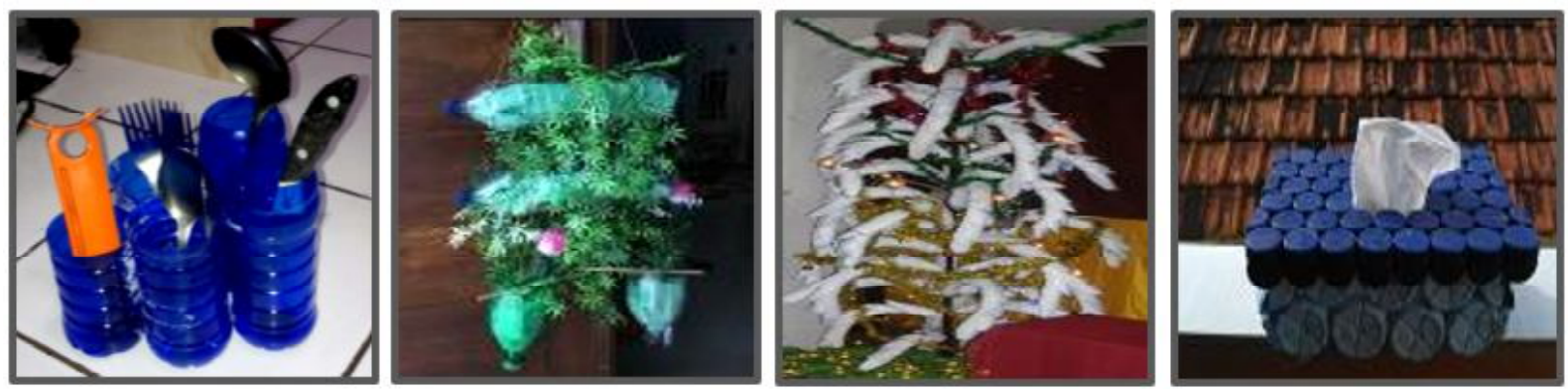

Gambar 8. Hasil karya peserta program pengabdian pada masyarakat

Tujuan dari adanya pelaksanaan display karya ini dimaksudkan agar pihak peserta dan mitra dapat mengetahui hasil dan penerapan produk hiasan memanfaatkan sampah plastik yang telah dibuat oleh para peserta yang secara langsung. Selain itu, agar pihak mitra dapat memberikan penilaian kepada pihak pelaksana dan peserta yang merupakan warga sekitar tempat pelaksanaan dalam menambah pengetahuan mengenai pengembangan suatu kemampuan serta produk yang berdasar kepada bahan bekas.

\section{Pembahasan}

\section{Relevansi bagi peserta}

Kegiatan program pengabdian pada masyarakat Universitas Mercu Buana dalam bentuk pemanfaatan sampah plastik sebagai material produk hiasan dengan aktiftas berupa pelatihan ini memiliki relevansi dengan kebutuhan penguasaan dari pemanfaatan suatu bahan yang telah ada dan tidak jarang dilupakan yaitu sampah plastik. Pada pelaksanaan program pengabdian berupa pelatihan ini, bertujuan untuk menambah pengetahuan peserta mengenai penguasaan dan penerapan suatu pengetahuan dalam hal desain yaitu penerapan bahan untuk diterapkan ke dalam suatu produk. Hal ini ditunjang dari komunikasi yang diberikan oleh pihak mitra kepada warga sekitar tempat pelaksanan mengenai dampak yang akan diterima oleh peserta. Oleh karena itu, dari target peserta yang berasal dari lulusan SMA menganggap dengan adanya program pengabdian pada masyarakat dalam bentuk pelatihan pemanfaatan sampah plastik ini dianggap dapat membantu mereka untuk menambah pengetahuan mengenai adanya teknik dan proses dari pemanfaatan sampah plastik untuk dapat dijadikan produk hiasan.

\section{Hasil pelatihan}

Berdasarkan dari hasil wawancara tidak terstruktur antara tim pelaksana dan peserta yang disertakan dengan pengamatan langsung selama kegiatan, maka pelaksanaan kegiatan program pengabdian kepada masyarakat oleh tim pelaksana dari Universitas Mercu Buana memberikan hasil sebagai berikut: (1) dari pelaksanaan kegiatan program pengabdian pada masyarakat ini telah meningkatkan dan menambah pengetahuan kepada lulusan SMA dalam berpraktik dan berkarya dalam menghasilkan produk serta melatih ketrampilan praktik pemanfaatan sampah plastik. Peningkatan pengetahuan dapat dilihat dari adanya hasil berupa produk hiasan yang dihasilkan oleh peserta. Selain itu, bertambahnya pengetahuan peserta dapat dilihat dari keaktifan peserta dalam mengikuti program dari awal sampai akhir karena dalam praktiknya, pada setiap pertemuan, tim pelaksana memberikan infromasi yang berbeda dalam hal teoritis dan praktik 


\section{Pelatihan Pemanfaatan Sampah Plastik sebagai Material Produk Hiasan bagi Lulusan SMA...}

Ali Ramadhan, Lelo Lelo, Ridwan Rasyid

yang secara langsung wajib diikuti oleh peserta. (2) Meningkatnya pengetahuan peserta mengenai pemanfaatan bahan dan salah satunya bahan baku yang berasal dari sampah serta adanya pengetahuan tambahan mengenai proses pembuatan produk yang memanfaatkan sampah plastik. Hal ini dikarenakan dengan adanya metode pelaksanaan berupa studi kasus dalam pemanfaatan sampah plastik, dapat memfokuskan pengetahuan peserta mengenai proses pemanfaatan sampai ke tingkat penerapan sampah plastik sampai menjadi produk yang dikhususkan kepada produk hiasan.

\section{Faktor pendukung}

Dalam pelaksanaan program pengabdian pada masyarakat ini terdapat beberapa faktor yang mendukung terlaksananya kegiatan pengabdian pada masyarakat ini yaitu: (1) adanya bantuan yang dilakukan oleh pihak mitra dalam memberikan fasilitas berupa tempat pelaksanaan dan peserta yang merupakan warga dengan kategori lulusan SMA untuk terlibat langsung dalam pelaksnaan serta mensukseskan program pengabdian pada masyarakat dalam bentuk pelatihan ini. (2) Adanya minat dan antusiasme peserta pada saat kegiatan berlangsung. Yang dapat terlihat dari jumlah peserta yang tidak mengalami pengurangan serta respon peserta dalam melakukan praktik. Selain itu, besarnya minat dapat dilihat juga melalui tanya jawab yang bertujuan untuk mendapatkan informasi dari tim pelaksana yang dilakukan pada saat praktik. (3) Tidak adanya aktifitas lain yang mengganggu dari berlangsungnya program pengabdian pada masyarakat ini. Hal ini dikarenakan dalam prosesnya, program pengabdian ini telah meminta izin terlebih dahulu kepada elemen ketua masyarakat dari tingkat RT, RW dan pihak keamanan tempat berlangsungnya program pengabdian pada masyarakat ini. Selain itu, dikarenakan peserta yang telah saling kenal, maka tidak ada kecanggungan antara peserta, sehingga dalam berkomunikasi tidak canggung. (4) Adanya kesediaan konsumsi oleh warga sekitar pada saat pelaksanaan program pengabdian pada masyarakat. Konsumsi diberikan oleh pihak mitra dan warga dari sekitar tempat pelaksanaan, sehingga peserta dan tim pelaksana tidak perlu mengeluarkan biaya lebih untuk mendapatkan konsumsi.
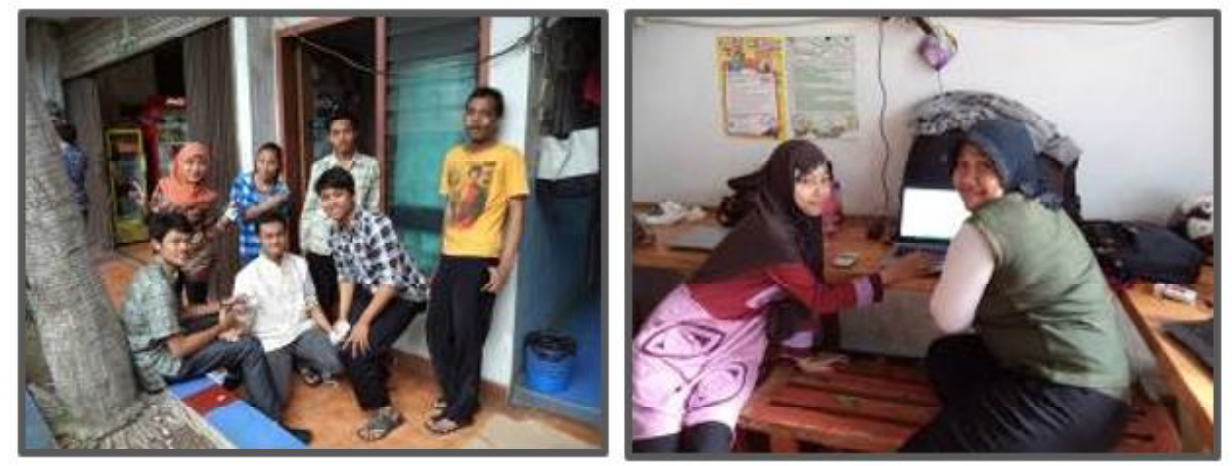

Gambar 9. Peserta yang aktif sebagai faktor pendukung dalam kegiatan

\section{Faktor Penghambat}

Dalam pelaksanaan program pengabdian pada masyarakat ini terdapat beberapa faktor penghambat yang terjadi pada saat pelaksanaan aktiftas yaitu: (1) karena pelatihan yang dilaksanakan berupa pelatihan secara langsung, perlu adanya penjelasan berupa praktik kepada peserta di setiap pertemuannya. Hal ini didasari oleh pengetahuan peserta yang memang baru mengetahui adanya teknik pemanfaatan sampah 
ABDIMAS: Jurnal Pengabdian Masyarakat Universitas Merdeka Malang

Volume 5, No 1, Maret 2020: 1-17

plastik dan metode pengolahannya. (2) Adanya peserta yang merasa jijik pada saat melakukan praktik. Hal ini dikarenakan pada awal pertemuan, tim pelaksana belum memberikan gambaran mengenai karakteristik bahan yang akan dipakai. Sehingga peserta masih membayangkan bahan yang dipakai berupa sampah yang bekesan jorok dan kotor. (3) Adanya penghambat berupa metode pelaksanan pengajaran dari pelatihan ini yang menitikberatkan kepada metode praktik yang terkadang terdapat peerta yang masih perlu bantuan dalam bentuk bimbingan untuk memberitahukan mereka mengenai tahap yang harus dilakukan. (4) Jangka waktu yang dibatasi sehingga perlu adanya pembagian waktu yang jelas dalam pelaksanaan program pengabdian pada masyarakat ini, serta kurangnya fasilitas untuk membuat suatu rancangan seperti meja untuk menggambar. Sehingga peserta masih perlu memanfaatkan lantai untuk membuat gambar rancangan. Hal ini masih dalam batas kewajaran karena fasilitas tempat yang digunakan merupakan fasilitas yang dimiliki oleh wilayah RT dan RW setempat dan bukan sebagai fasilitas untuk ruang kerja perancangan.

\section{SIMPULAN DAN SARAN}

\section{Simpulan}

Program pengabdian pada masyarakat ini bertujuan untuk memberikan pelatihan ketrampilan dan pengetahuan baru kepada para peserta yang merupakan lulusan sekolah menengah atas di Kota Tangerang tentang pemanfaatan sampah plastik sebagai bahan untuk membuat produk hiasan. Target yang hendak dicapai dalam program ini adalah peserta mampu mengetahui dan mengolah bahan utama berupa sampah plastik menjadi produk hiasan yang lebih bermanfaat. Pelaksanaan program ini dibagi dalam 2 tahapan yaitu tahap pelaksanaan dan tahap evaluasi. Fasilitas peralatan dan penunjang, ketersediaan tempat, keterlibatan mitra, serta dukungan dari masyarakat menjadi faktor utama keberhasilan pencapaian tujuan program ini. Hasil yang dicapai berupa kemampuan siswa dalam mendaur ulang sampah plastik, mengolah sampah plastik, serta membuat produk hiasan yang lebih kreatif dan memberikan nilai tambah dan nilai jual. Diharapkan dengan kegiatan ini siswa turut berperan dalam menjaga lingkungan di sekitarnya dengan memanfaatkan sampah plastik menjadi produk yang bermanfaat, serta menjadi lebih mandiri dalam memperoleh penghasilan.

\section{Saran}

Perlu adanya sosialisasi serta promosi mengenai adanya program ini, sehingga peserta tidak terbatas pada lulusan SMA yang berada di satu wilayah saja. Seiring dengan banyaknya ragam jenis sampah plastik, maka perlu adanya tambahan waktu pelaksanaan untuk memberikan pengetahuan yang cukup tentang pengolahan bahan, desain, produk, dan penciptaan produk hiasan. Perlu dilakukan pendampingan dan monitoring secara berkesinambungan kepada para mitra agar program ini dapat dilanjutkan secara berkala. Sebaiknya program dapat ditindaklanjuti melalui kerjasama dengan mitra-mitra lain atau pihakpihak lain di luar institusi, agar dapat mengetahui respon secara lebih luas terhadap pelaksanaan suatu program pengabdian pada masyarakat yang telah dilakukan. Pihak mitra dapat memberikan informasi yang dapat bermanfaat mengenai kebutuhan yang selaras antara kemampuan dan pengetahuan yang akan digunakan untuk dapat melaksanakan program pengabdian pada masyarakat yang sejenis. 


\section{DAFTAR PUSTAKA}

Abarna, R., Sakthi, R., Sakthivel, B., Sandeeshkumar, K., \& Saranraj, S. (2019). Design and analysis of mini injection moulding machine for recycling of plastic wastes. South Asian Journal of Engineering and Technology, 8(2), 312-323.

Adam, S. (1992). Dasar-dasar Mikrobiologi Parasitisme untuk Perawat. Jakarta: Penerbit Buku Kedokteran EGC.

Agustin, D. (2018). Desain booth display ramah lingkungan untuk pemasaran produk olahan hasil tambak. Jurnal Envirotek, 10(1). https://doi.org/10.33005/envirotek.v10i1.1168

Ahvenainen, R. (2003). Modern Plastics Handbook. $1^{\text {st }}$ Edition. United Kingdom: Woodhead Publishing Limited.

Amalia, A. R., \& Uswatun, D. A. (2019). Analisis respon mahasiswa dalam penerapan group work rules pada metode presentasi di program studi pendidikan guru sekolah dasar. Jurnal Holistika, 3(2), 81-88.

Anita, R. R., \& Puspitasari, C. (2019). Penerapan olahan limbah kantong plastik dengan Teknik Crochet sebagai unsur dekoratif pada produk fesyen. Jurnal Atrat, 7(1), 81-91

Arico, Z., \& Jayanthi, S. (2017). Pengolahan limbah plastik menjadi produk kreatif sebagai peningkatan ekonomi masyarakat pesisir. Martabe: Jurnal Pengabdian Kepada Masyarakat, 1(1), 1-6. http://dx.doi.org/10.31604/jpm.v1i1.1-6

Bell, S. (2019). Elements of Visual Design in the Landscape. London: Routledge.

Charter, M., \& Tischner, U. (2017). Sustainable Product Design. In Sustainable Solutions. London: Routledge.

Clark, R. C. (2019). Evidence-based Training Methods: A Guide for Training Professionals. Virginia: American Society for Training and Development.

Crawford, R. J., \& Martin, P. J. (2020). Plastics Engineering. Oxford: Butterworth-Heinemann.

De Aguiar, J., de Oliveira, L., da Silva, J. O., Bond, D., Scalice, R. K., \& Becker, D. (2017). A design tool to diagnose product recyclability during product design phase. Journal of Cleaner Production, 141, 219-229. https://doi.org/10.1016/j.jclepro.2016.09.074

Gargiulo, R. M., \& Bouck, E. C. (2019). Special Education in Contemporary Society: An Introduction to Exceptionality. Sage Publications, Incorporated.

Hand, C. (2018). Working in Trash and Recycling Collection. New York: The Rosen Publishing Group, Inc.

Harper, K. H. (2017). Aesthetic Sustainability: Product Design and Sustainable Usage. London: Routledge.

Hasan, A. D. (2019). Study of Decorative Variety in Gorontalo Karawo Fabric in Aesthetic and Symbolic Elements. ARTic, 3, 121-134. https://doi.org/10.34010/artic.2019.3.2506.121-134

Hernawati, D., \& Amin, M. (2017). Analisis self efficacy mahasiswa melalui kemampuan presentasi di kelas. Education and Human Development Journal, 2(1), 26-33 https://doi.org/10.33086/ehdj.v2i1.379

Lewis, H., Gertsakis, J., Grant, T., Morelli, N., \& Sweatman, A. (2017). Design Environment: A Global Guide to Designing Greener Goods. London: Routledge. 
ABDIMAS: Jurnal Pengabdian Masyarakat Universitas Merdeka Malang Volume 5, No 1, Maret 2020: 1-17

Merrington, A. (2017). Recycling of plastics: In Applied Plastics Engineering Handbook. New Jersey: William Andrew Publishing.

Muhsinin, S., Dinata, D. I., Andriansyah, I., \& Asnawi, A. (2019). Peningkatan potensi ibu rumah tangga dalam mengolah sampah organik rumah tangga menggunakan Metode Takakura di Desa Cibiru Wetan, Kabupaten Bandung. Jurnal Pengabdian pada Masyarakat, 4(2), 179 186.

https://doi.org/10.30653/002.201942.110

Ormondroyd, G. A., \& Morris, A. F. (Eds.). (2018). Designing with Natural Materials. Florida: CRC Press.

Paulinan, P., \& Purwanto. (2001). Penulisan Bahan Ajar. Jakarta: Pusat Antar Universitas dan Pengembangan Aktivitas Instruksional: Direktorat Jenderal Pendidikan Tinggi, Depdiknas.

Pivnenko, K., Eriksen, M. K., Martín-Fernández, J. A., Eriksson, E., \& Astrup, T. F. (2016). Recycling of plastic waste: presence of phthalates in plastics from households and industry. Waste Management, 54, 44-52. https://doi.org/10.1016/j.wasman.2016.05.014

Putra, H. P., \& Yuriandala, Y. (2010). Studi pemanfaatan sampah plastik menjadi produk dan jasa kreatif. Jurnal Sains \& Teknologi Lingkungan, 2(1), 21-31. https://doi.org/10.20885/jstl.vol2.iss1.art3

Ragaert, K., Delva, L., \& Van Geem, K. (2017). Mechanical and chemical recycling of solid plastik waste. Waste Management, 69, 24-58. https://doi.org/10.1016/j.wasman.2017.07.044

Rusman. (2011). Pembelajaran Berbasis Teknologi Informasi dan Komunikasi: Mengembangkan Profesionalisme Guru. Jakarta: Rajawali Pers.

Savitri, S., \& Sriwardani, N. (2018). Produk tradisional Sunda sebagai elemen dekoratif pada desain interior. Jurnal Atrat, 6(2), 109-115

Schwartz, M. (2016). Encyclopedia and Handbook of Materials, Parts, and Finishes. Florida: CRC press.

Selke, S. E., \& Culter, J. D. (2016). Plastics Packaging: Properties, Processing, Applications, and Regulations. München: Carl Hanser Verlag GmbH Co KG.

Setiyawan, P. E. (2016). Penyuluhan tentang pengelolaan sampah dan pembuatan tempat sampah unik dari pipa PVC untuk masyarakat Desa Srigading Kecamatan Lawang. Abdimas: Jurnal Pengabdian kepada Masyarakat Universitas Merdeka Malang, 1(1), 30-35.

https://doi.org/10.26905/abdimas.v1i1.1172

Sholihah, F. A., Normaladewi, A., \& Laksono, P. T. (2019). Pengolahan plastik bekas menjadi bantal hias di Desa Ngempit Kecamatan Kraton Kabupaten Pasuruan. JIPEMAS: Jurnal Inovasi Hasil Pengabdian Masyarakat, 2(1), 9-17. https://doi.org/10.33474/jipemas.v2i1.1640

Singh, J., \& Ordoñez, I. (2016). Resource recovery from post-consumer waste: important lessons for the upcoming circular economy. Journal of Cleaner Production, 134, 342-353. https://doi.org/10.1016/j.jclepro.2015.12.020

Singh, N., Hui, D., Singh, R., Ahuja, I. P. S., Feo, L., \& Fraternali, F. (2017). Recycling of plastic solid waste: A state of the art review and future applications. Composites Part B: Engineering, 115.

Sukrorini, T., Budiastuti, S., Ramelan, H. A., \& Kafiar, P. F. (2014). Kajian dampak timbunan sampah terhadap lingkungan di tempat pembuangan akhir (TPA) Putri Cempo Surakarta. Jurnal Ekosains, 6(3). 
Pelatihan Pemanfaatan Sampah Plastik sebagai Material Produk Hiasan bagi Lulusan SMA... Ali Ramadhan, Lelo Lelo, Ridwan Rasyid

Sulistiyorini, N. R., Darwis, R. S., \& Gutama, A. S. (2015). Partisipasi masyarakat dalam pengelolaan sampah di lingkungan Margaluyu Kelurahan Cicurug. SHARE: Social Work Journal, 5(1).

Sunarjo, \& Yuniarti, S. (2017). Pemanfaatan sayur buangan untuk pakan Cacing African Night Crawler (ANC) sebagai bahan pembuat pellet. Abdimas: Jurnal Pengabdian kepada Masyarakat Universitas Merdeka Malang, 2(1), 43-49. https://doi.org/10.26905/abdimas.v2i1.1290

Surdia, T \& Saito, S. (2005). Pengetahuan Bahan Teknik. Jakarta: Pradnya Paramita

Swift, E. (2018). Style and function in Roman decoration: Living with Objects and Interiors. London: Routledge.

Zainuddin, D., Wiratmani, E., \& Usman, R. (2019). Pengabdian Kepada Masyarakat Anggota Pemberdayaan Kesejahteraan Keluarga di Kelurahan Cinere dan Kelurahan Gandul Depok Jawa Barat. Abdimas Universal, 1(2).1-4. https://doi.org/10.36277/abdimasuniversal.v1i2.28 